\title{
PRISPEVEK K INTEGRACIJI PROSTORSKEGA, SOCIALNEGA, GOSPODARSKEGA IN OKOLJSKEGA NAČRTOVANJA
}

\author{
Andrej Pogačnik \\ Fakulteta za gradbeništvo in geodezijo, Katedra za prostorsko planiranje \\ email: apogacnik@fgg.uni-lj.si \\ Izvirni znanstveni članek
}

COBISS 1.01

\section{Izvleček}

Prispevek podaja kratek pregled in razmišljanje o metodah integracije raznih sektorjev načrtovanja v celostno, interdisciplinarno, integrativno načrtovanje. Avtor se kritično odziva na sedanje razmere $\mathrm{v}$ stroki in daje svoje pobude za metode integralnega načrtovanja. V tabeli opiše minimalne prostorske kazalce in njihove povezave $\mathrm{z}$ gospodarskimi, socialnimi in okoljskimi vidiki. Delovanje modela konceptualno prikaže na treh strateških primerih presojah možnosti razvoja gospodarske, turistične cone in območja turizma.

Ključne besede: Metodologija planiranja, integralno prostorsko planiranje, interdisciplinarnost, regionalni razvojni programi, regionalni razvojni projekti.

\section{CONTRIBUTION TO THE INTEGRATION OF SPATIAL, SOCIAL, ECONOMIC AND ECOLOGICAL PLANNING}

\begin{abstract}
In the article the author describes the history of interdisciplinary planning. He comments the development and state-of-the-arts in this field. He gives his own proposal for the new generation of comprehensive plans in Slovenia in terms of interdisciplinary approach. In a large table the key spatial indicators are described together with its links with economic, social and ecological indicators. The method is demonstrated on three practical cases in a form of flowcharts. Strategic evaluations of industrial, touristic and agricultural zones are examined.
\end{abstract}

Key words: planning methodology, integrative spatial planning, interdisciplanarity, regional development programs, regional development projects. 
Integracija različnih disciplin $\mathrm{v}$ planiranju je nikoli dokončana zgodba. V svoji polstoletni zgodovini je doživljala svoje vzpone in padce, navdušeno podporo in uničujočo kritiko. Po obdobju naglega kapitalističnega razvoja po drugi svetovni vojni - v 50-tih in 60-tih letih - so se levo usmerjene zahodnoevropske vlade vse bolj zavedale pomena okoljskih, socialnih, javnofinančnih in drugih sestavin v prostorskem načrtovanju. Prednjačile so skandinavske države, Holandija, Anglija in Nemčija. Vznikale so številne planerske šole, ki so oblikovale docela nov tip poklica- družbenega planerja. Zlasti univerzitetni in raziskovalni centri so razvijali aplikacije statističnih metod in numerične modele kot podpore integrativnemu načrtovanju. Prav celostno planiranje, nekak državni prostorski kapitalizem, je blažilo učinke krize mest, študentskih gibanj, marginalizacije nekaterih družbenih skupin, degradacije okolja, pomanjkanja energije, $v$ času prve resne povojne krize kapitalizma.

Države socializma so, realno gledano, najbolj učinkovito izvajale celostno planiranje, čeprav temelječe na nedemokratični, netržni, centralizirani družbeni ureditvi. Že pred drugo svetovno vojno razvoj industrijsko rudarskih regij na Uralu, v Doneckem bazenu ne bi bili možni brez planskega gospodarstva. Elektrarna Bratsk, Nowa Huta, Togliattigrad so temeljili na centraliziranem odločanju, a tudi integraciji vseh sektorjev načrtovanja. Učinkovitost celostnega načrtovanja je Sovjetska zveza uspešno izvažala - z izgradnjo asuanskega jezu, na primer.

Po ponovni desni prevladi v zahodni Evropi in Združenih državah, z Reaganizmom in Thacherizmom so se integrativni pristopi k prostorskemu načrtovanju razblinili. Prostor je ponovno krojila logika trga, profita in kapitala. Kot ponavadi - učinkovito.

Jugoslavija je doživljala pozornost - tudi razvitega zahoda - svojih originalnih modelov samoupravnega družbenega planiranja. Kardelj je bil med cenjenimi avtorji zahodnih akademskih krogov. $Z$ družbenim planiranjem je bilo sodelovanje raznih vidikov načrtovanja uzakonjeno, čeprav brez prave metodološke podpore in še zlasti brez podpore v zemljiški politiki in drugih mehanizmov implementacije.

Konec 80-tih in v 90-tih letih je kapitalizem pometel $\mathrm{z}$ centraliziranimi metodami planiranja v nekdanjih državah socializma, vključno s Slovenijo. Razvoj v prostoru je stopil na pot turbo kapitalizma ne le v vzhodni Evropi in Rusiji, pač pa tudi na Kitajskem in Vietnamu. Kitajska je kljub tržni liberalizaciji v prostoru zadržala tudi vzvode centralnega planiranja. Hidroenergetski sistem na Jang-tse-kjangu je morda zadnja in največja implementacija celostnega načrtovanja: javnofinančnih virov, stroškov in koristi zaradi več elektrike, manj poplav, varnejše plovbe, a tudi preselitve stotisočev ljudi, izgube naravnih vrednot $»$ treh sotesk «.

Konec 20. stoletja in v začetku sedanjega se je trda linija tržnega kapitalizma v prostorskem urejanju ponovno začela mehčati, v nekaterih državah pa itak ni nikoli prevladala. Nujnosti varstva okolja in narave, Kyotski sporazum, direktive EU, ESDP, okrepljen pomen avtonomnosti načrtovanja na lokalni ravni, skrbna poraba vedno preskromnih proračunskih sredstev - vse našteto utrjuje pomen interdisciplinarnega načrtovanja danes v Evropi in svetu. Tudi tkim. tranzicijske države vse bolj ščitijo okolje, naravo, javno dobro in postavljajo meje nebrzdanemu kapitalističnemu eksploatiranju prostora.

Slovenska zgodba je znana. Po razpadu družbenega sistema načrtovanja je tudi de iure prenehalo sodelovanje gospodarskega, prostorskega, socialnega in drugih sektorjev planiranja. 
Prostorsko načrtovanje je znova (p)ostalo samostojno. Z prostorsko zakonodajo iz leta 2003 so se vsaj na strateški ravni dokumentov znova okrepile težnje k večji integraciji, tokrat zlasti okoljskih, naravovarstvenih in zemljiškopravnih vsebin v prostorsko urejanje. Gospodarskofinančni vidik je postal obvezen za prostorske ureditve javnega sektorja, socialno demografski vidik pa posebno skozi policentrični sistem naselij, potrebno »dostopnost« do javnih servisov itd.

Mnogo večjo obvezo za celostnim načrtovanjem v prostoru pa je postavil Zakon o skladnejšem regionalnem razvoju in iz njega izhajajoči regionalni razvojni programi. Tokrat se je situacija obrnila na glavo glede na prostorske plane, v katerih je prevladovala logika fizičnega načrtovanja. RRP-ji so vključevali zlasti okoljsko, gospodarsko komponento ter »človeške vire«, prostorske pa skoraj ne. Pa saj jih itak niso »pisali« prostorski načrtovalci. Tudi prave povezave med regionalno zasnovo prostorskega razvoja in regionalnimi razvojnimi programi (še) ni, tudi zaradi izrazito različnih časovnih planskih horizontov.

Danes smo priče ponovnega vzpona integralnih metod planiranja. K njim nas silijo tudi obvezne metodologije po katerih lahko projekti računajo na (so)financiranje iz EU skladov. Že Ropova strategija razvoja Slovenije, sledeča lizbonskih ciljem, je izrazito težila k interdisciplinarnosti pristopa. Nova generacija regionalnih razvojnih programov naj bi temeljila na obvezni metodologiji minimalnih skupnih kazalcev gospodarskega, socialno-demografskega, okoljskega in prostorskega razvoja. Zanimivo, da najnovejši predlogi sprememb prostorske zakonodaje (julij 2005) zopet zmanjšujejo pomen celostnega načrtovanja, saj vsaj na lokalni ravni ukinjajo strateško načrtovanje- za katero je interdisciplinarna metoda najbolj pomembna. Morda gre - sledeč bolj desni orientaciji Janševe vlade - za večji laissez faire $\mathrm{v}$ prostoru.

Integracija raznih sektorjev oziroma disciplin načrtovanja je predmet brezštevilnih zakonov, priročnikov, pravilnikov, metodologij, študij, raziskav in vzorčnih projektov po celem svetu. O njej je orjaška literatura. Skoraj ni kongresa, ki ne bi bil vsaj deloma posvečen tej tematiki. Pa vendar si mora vsaka država v nepregledni množici »vzorov« sama utirati pot $\mathrm{k}$ svoji metodologiji. V primeru držav članic EU v okviru glavnih zahtev, ki jih terjajo Eurostat, Espon, pravilniki delovanja raznih skladov, direktive itd. Ker je prostorsko načrtovanje $\mathrm{v}$ domeni vsake države članice, je tudi metodološka povezava prostorskega urejanja z drugimi vidiki načrtovanja različna od države do države.

V razliko od ekonomskega planiranja (deloma pa tudi od demografskega oz. načrtovanja človeških virov in okoljskega) prostorsko načrtovanje operira s prevelikim številom podatkov oziroma kazalnikov, kar otežuje integrativne metode. Zato je ena od težkih nalog reducirati prostorske indikatorje na nekaj ključnih.

Avtorjev prispevek v tem referatu je poskus definiranja ključnih prostorskih kazalcev, ki so »potrebni in zadostni«, utemeljeni s povezavami s gospodarskimi kazalci, s kazalci človeških virov, okolja in rabe naravnih dobrin, kar prikazuje tabela na naslednjih treh straneh. Podani so opisi učinkovanja kazalcev in vplivov to je povezav z drugimi sektorji planiranja

V zaključku tega prispevka prikazujemo tri primere shem, ki kažejo »delovanje« sistema integracije (prostora, okolja, gospodarstva in človeških virov). Gre za praktične primere proučitve možnih projektov gospodarske in turistične cone ter območja intenzivnega 
kmetijstva. V shemah smo poleg opisanih glavnih »sektorjev« presojanja dodali še dve dodatni presoji o ustreznosti razvoja določene rabe prostora. Ti dve presoji sta »konkurenca« v širšem prostoru (regije, države, v mednarodnem merilu) in pa presoja siceršnjih opcij, ki jih prostor nudi. Če občina (regija) nima drugih razvojnih opcij, moramo »znižati« strogost kriterijev in prevzeti več tveganja za okolje, za investitorje, sprejeti tudi slabše človeške in prostorske resurse. Če pa ima prostor (v celostnem smislu) več realnih razvojnih možnosti, lahko kriterije strateškega odločanja bistveno bolj zaostrimo.

Podobno deluje tudi »varovalka« konkurence. Če je tekmovalnost v sosednjih občinah, regijah, državah premočna bomo ali izjemno zaostrili kriterije ocenjevanja ali pa pobudo opustili. In obratno, če je konkurenca šibka, če so potrebe trga velike, bomo znižali kriterije in forsirali razvoj v tej smeri.

»Okenca« v konceptualnem diagramu polnimo z realnimi količinami - hektarji, razdaljami, cenami, sredstvi, prebivalci, stopnjami onesnaženja in drugimi. Nastavimo tudi glavne medsektorske povezave, akceleratorje in zaviralce razvoja, učinke grozdenja ali »izpiranja«, povratne zveze in podobno. V primeru, da pri presoji celega prostora pridemo do več alternativnih možnih lokacij, opravimo še dodaten izbor. Pri vsem opisanem pa je nujno, da se omejimo res na ključne indikatorje - sicer metoda postane nepregledna, prezahtevna, neoperativna.

\section{Literatura}

Keiner, Mettan, Schultz, 2002: Le controling dans la planification directrice cantonale. Geographica Helvetica, 2/2002.

Bizer, Sternberg, 2001: Grundprobleme von Indikatorensystem fuer Regionale Nachhaltigkeit, Raumordnung und Raumplanung 5-6/2001.

Kohezija na prelomu leta 2007 - zakonski predlogi evropske komisije o reformi kohezijske politike za obdobje 2007-2013. 2004: Evropska unija, Generali direktorat za regionalno politico, Informacijski bilten.

Structural indicators, http://www.europa.en.int/scad_plus.

Communication from the Comission - Structural indicators (COM/2002 551 final, Executive summary).

Pickett S.T.A., Cadenasso M.L., Grove J.M. 2004: Resiliem cities: meaning, models and metaphor for integrating the ecological, socio-economic, and planning realms. Landscape and urban planning G9 pp 369-384, Elsevier.

"Sasi” model. V European spatial planning observation network, 3. interim report, The Royal institute of technology, Stockholm, 2004.

Directive 2001/42/EC of the European Parliament and of the Council on the assessment of the effects of certain plans and programmes on the environment. Junij 2001.

Kontić B. et al. 2000:, Trajnostno regionalno razvojno načrtovanje: zbornik rezultatov projekta. Ljubljana, Regionalni center za okolje za srednjo in vzhodno Evropo. 
Prispevek k integraciji prostorskega, socialnega, gospodarskega in ...

\begin{tabular}{|c|c|c|c|c|c|}
\hline & 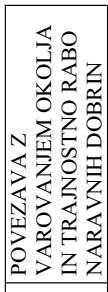 & 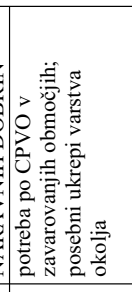 & 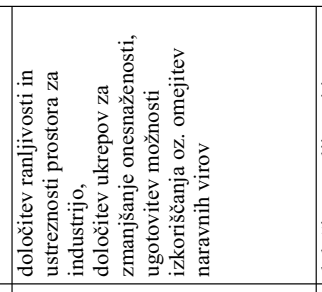 & 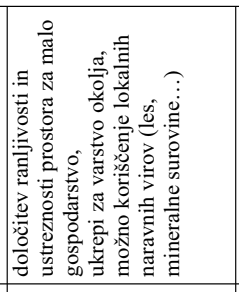 & 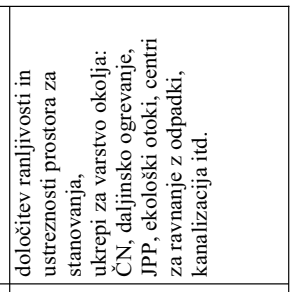 \\
\hline 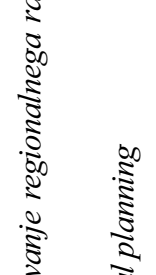 & 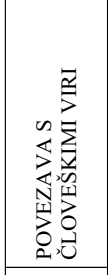 & 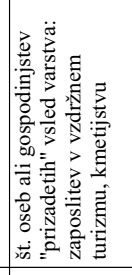 & 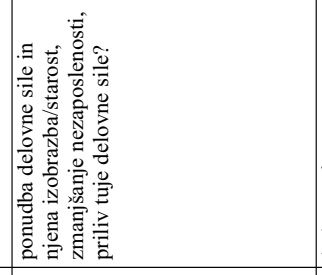 & 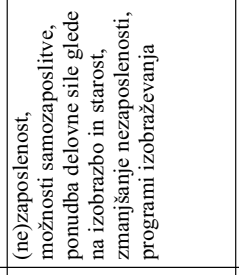 & 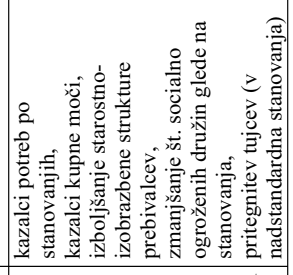 \\
\hline 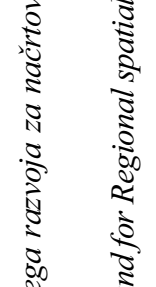 & 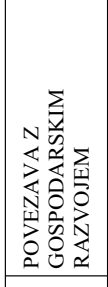 & 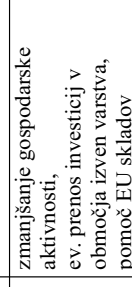 & 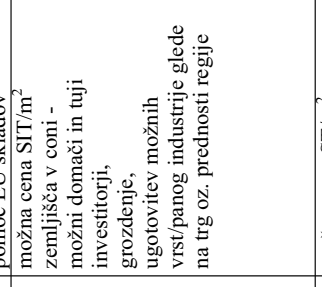 & 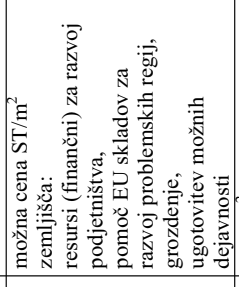 & 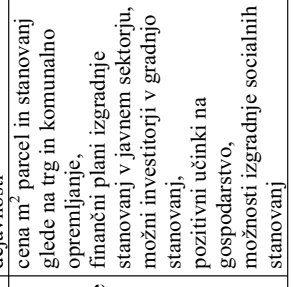 \\
\hline 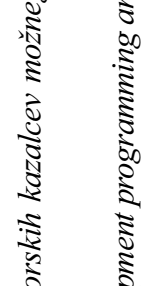 & 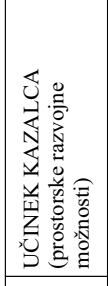 & 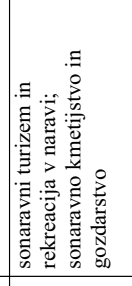 & 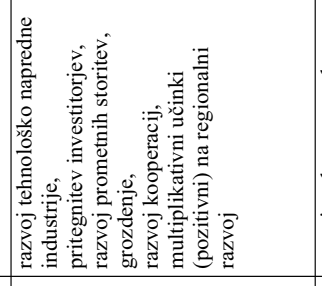 & 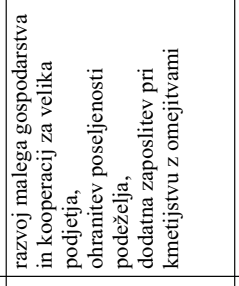 & 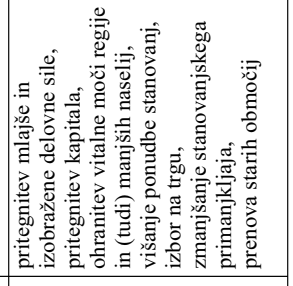 \\
\hline 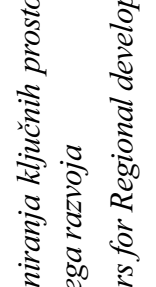 & 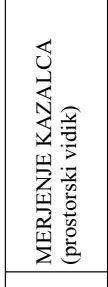 & 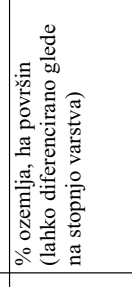 & 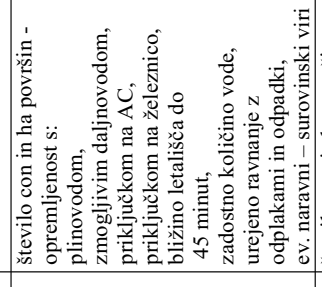 & 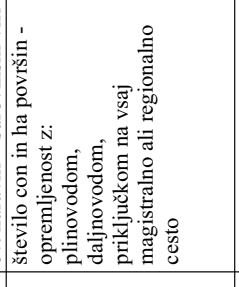 & 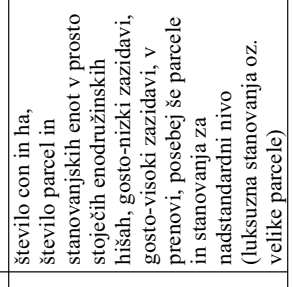 \\
\hline 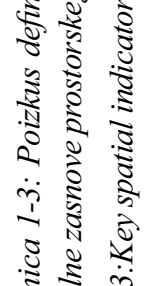 & 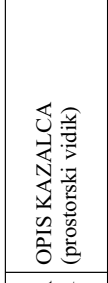 & 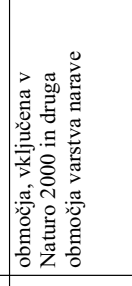 & 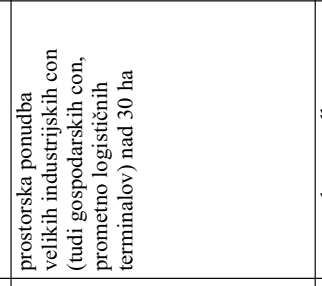 & 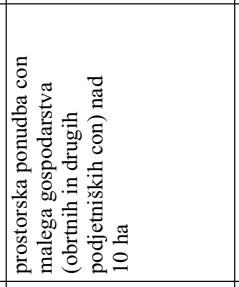 & 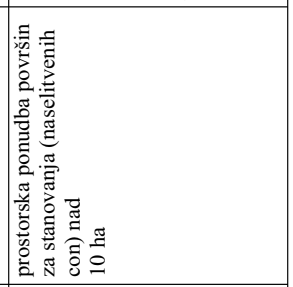 \\
\hline$\frac{5}{50} \frac{1}{5}$ & 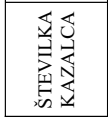 & . & $N$ & $m$ & 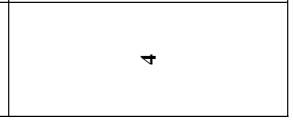 \\
\hline
\end{tabular}




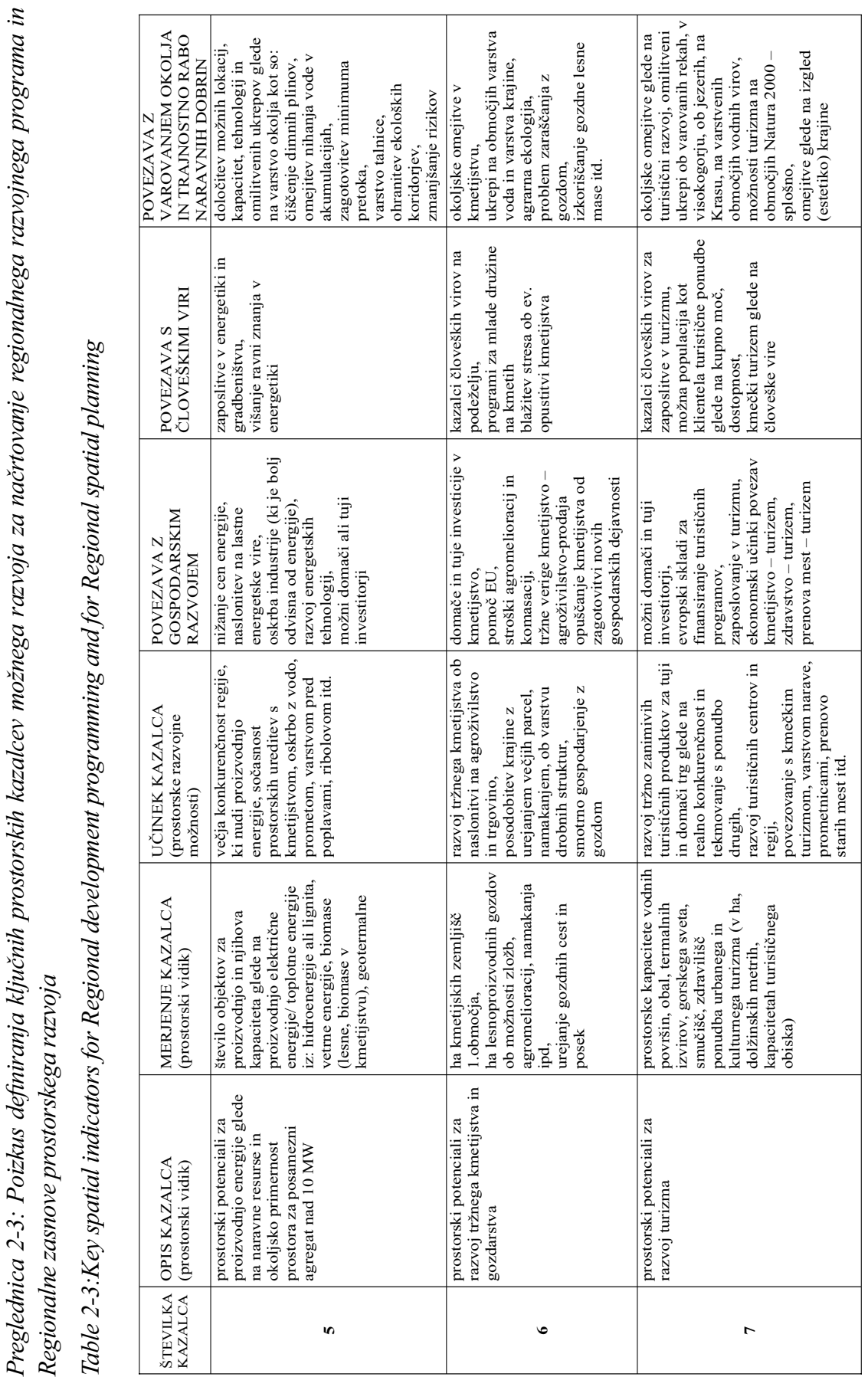




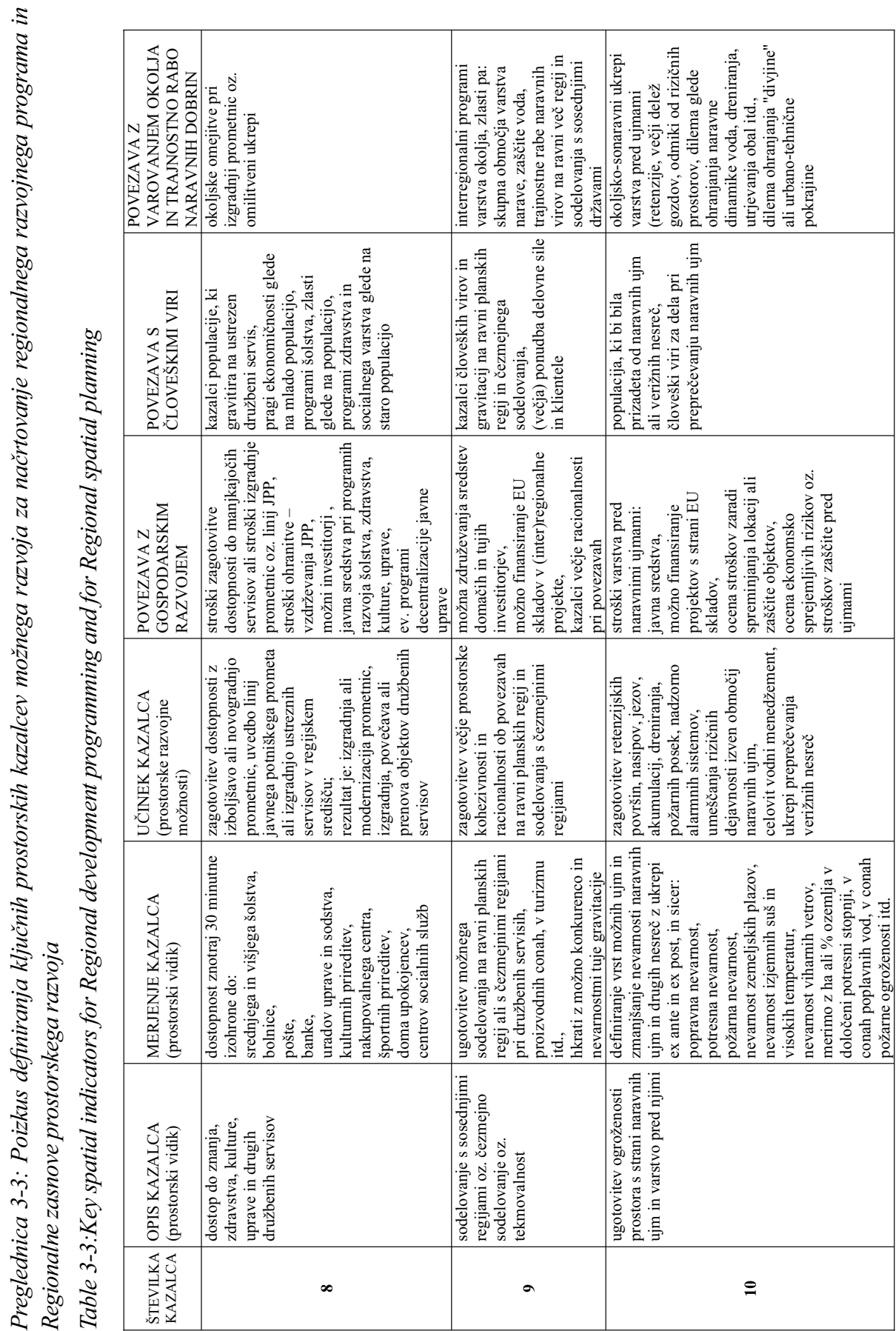



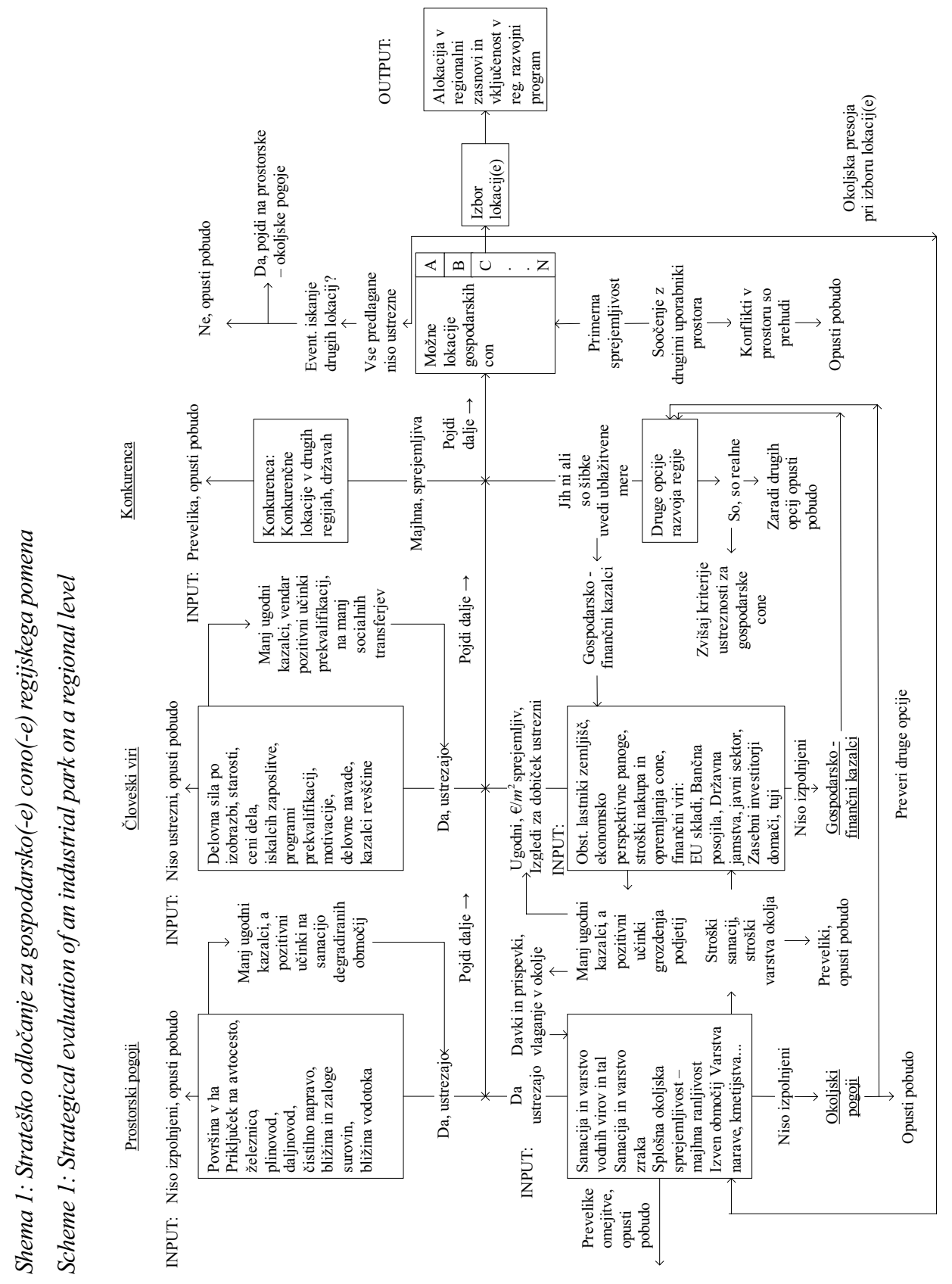

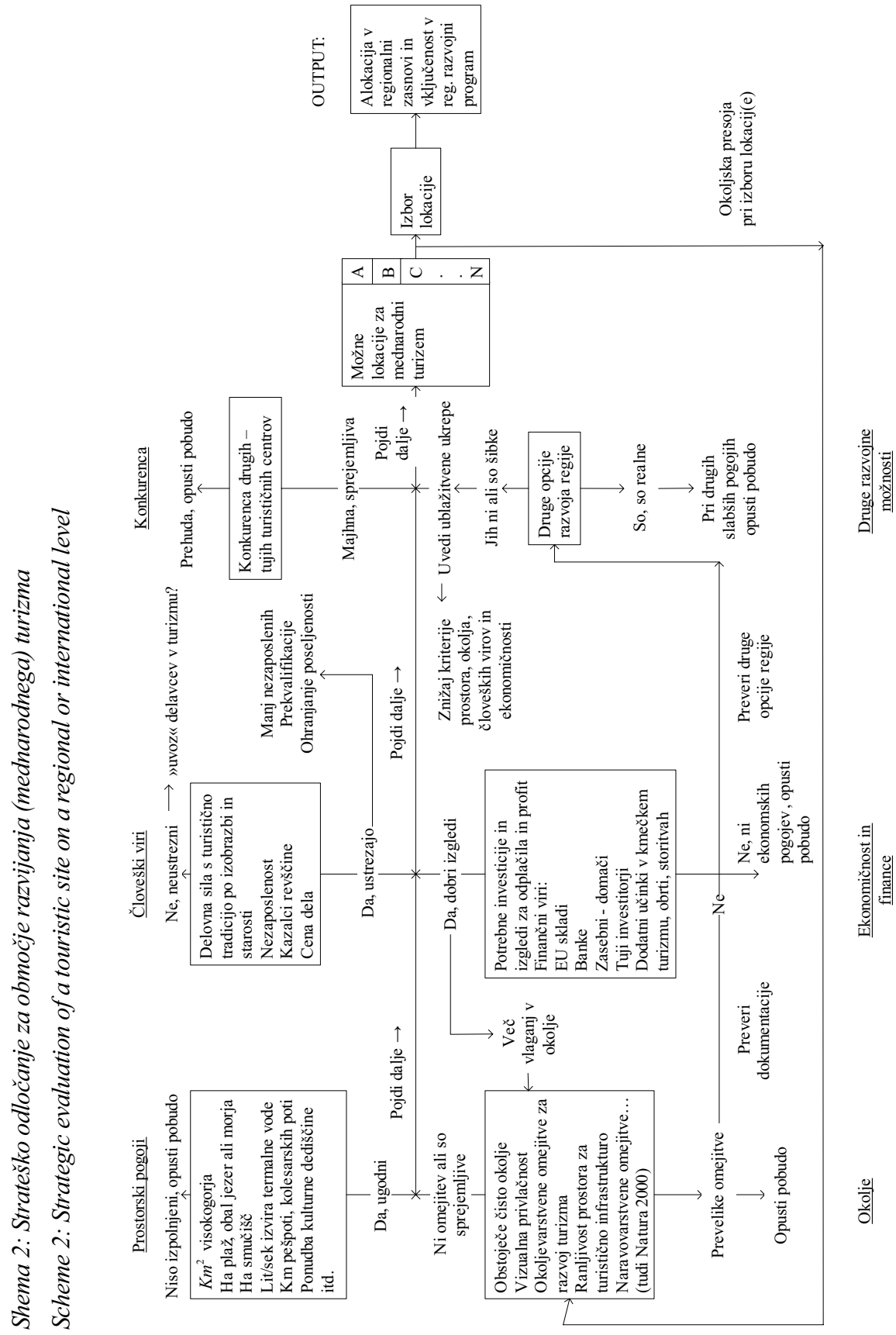

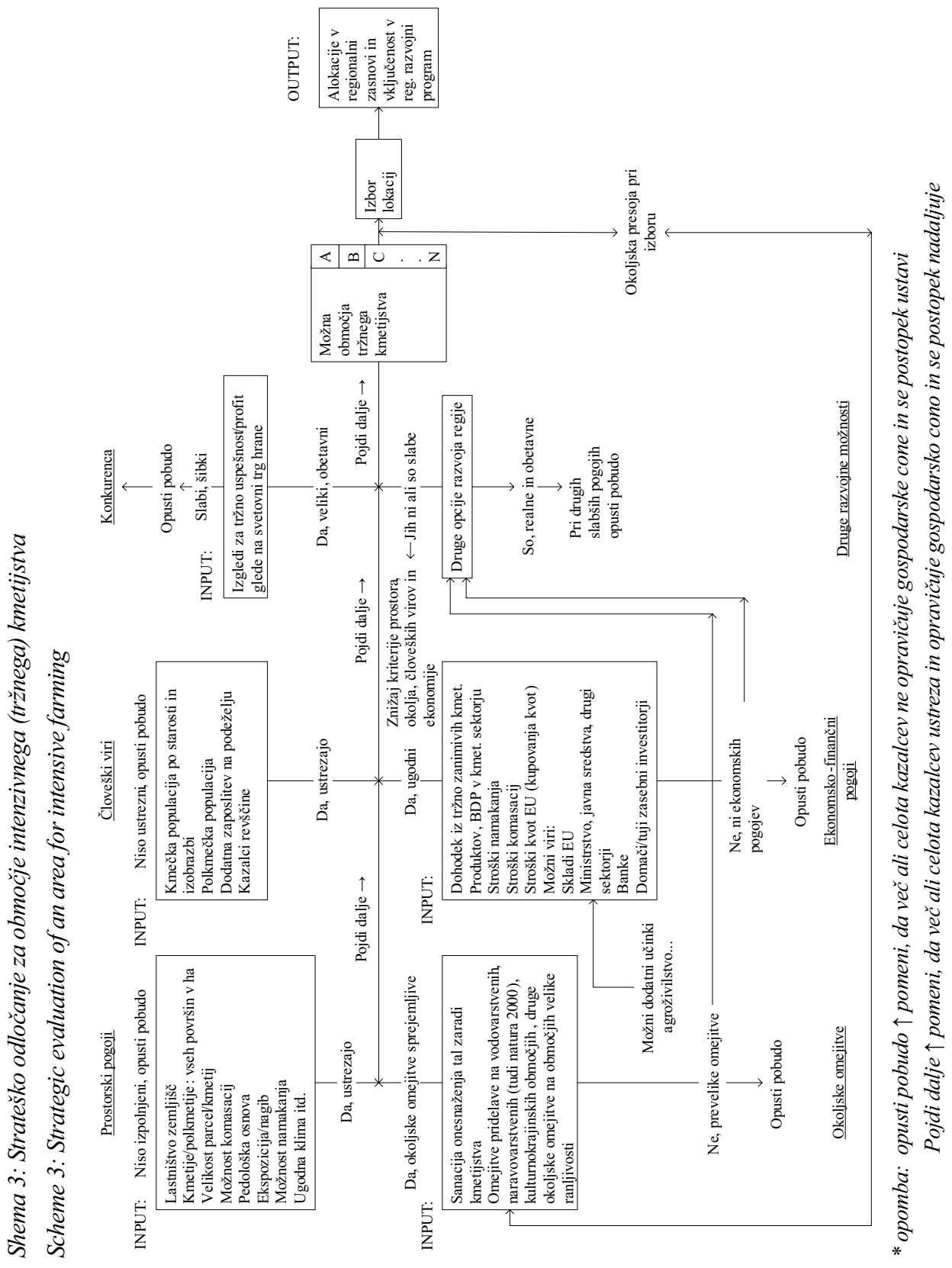


\title{
CONTRIBUTION TO THE INTEGRATION OF SPATIAL, SOCIAL, ECONOMIC AND ECOLOGICAL PLANNING
}

\begin{abstract}
Summary
The role of integrative, comprehensive planning varied through last fifty years. It was stronger in the periods of left-oriented governments and weak during the rule of right-oriented parties. After the second World War interdisciplinary approach became indispensable during the first ecological, political and urban crisis in 70-ties. Social-democratic governments encouraged the methods of societal planning that helped to overcome the problems of ecology, energy supplies, urban poverty, traffic congestion, student movements, and others. Great Britain, Scandinavian countries, Holland, West Germany were leading in this respect, United States with it's Chicago planning school were on top of the research in this field.

Eastern socialistic countries brought comprehensive planning to reality in a most efficient way. Soviet Union exported its experiences and technologies. Asuan Dam is probably the most known example.

Reaganism and Thatcherism diminished the role of comprehensive planning. Planning profession lost its field of work to a large extend. After the change of political systems in East European countries, together with Russia, new liberalism influenced spatial 'planning', too. It became subordinated to land market. Similarily is the case of China or Vietnam where dual system exists the one of central planning and liberal spatial planning.

The role of interdisciplinary methods in planning is encreasing in recent years again. European Union demands the complexity of project proposals in order to be financed by its various founds. Numerous EU directives are based on the integration of various disciplinary methods.

The case of Slovenia show increasingly role of interdisciplinarity, especially in the fields of regional development programs and regional spatial plans in the last decade.

The author develops the table of core spatial indicators which could be well connected with ecological, economical and social indicators. All disciplines, that are included into a planning process should reduce its key indicators to ten or less in order to keep comprehensive methods operational and effective. Of course, the indicators should be coordinated with the demands of EU (Eurostat, ESPON...) completely.

In the research discussed in this paper the method of integrative evaluation is demonstrated on three examples: the spatial location (and its feasibility) of the industrial park, touristic centre and the area of intensive farming. Besides the evaluation of the spatial potentials, human resources, financial resources and costs, ecological limitations - two additional view points are introduced. First the competition of neighboring zones, regional or international markets. Second, the influence of other options which are offered in the study area. In case of weak options or no options, the proposed development is favourised. In case of many other development alternatives, the criteria must be very strict (on the highest standards). In the case of a very intensive competition or weak market demands the evaluation criteria must be upgraded. Or, vice versa, in the case of weak competition or high market demands, the evaluation criteria could be lowered.
\end{abstract}

